\title{
Integrated application of geophysical loggings and fracture survey on rock exposures for identifying transmissive fractures in crystalline aquifer: case study in the city of São Paulo
}

\author{
Bruna Fiume ${ }^{1,2}$ (D), Amélia João Fernandes ${ }^{3}$ (D), Marcos Bolognini Barbosa' (D), \\ Ricardo Hirata ${ }^{1}$ (D), Reginaldo Antonio Bertolo ${ }^{*}$ (D)
}

\begin{abstract}
The integrated analysis of geophysical loggings for identifying transmissive fractures has had a limited use in Brazil, although a large number of studies have been conducted so far throughout the world. The application of those tools has gained a crescent importance as they are needed for characterizing groundwater contamination in fractured rock aquifers at a great number of industrial sites worldwide and in Brazil. This paper presents the analysis of data collected by caliper, optical televiewer (OPTV), acoustic televiewer (ATV) and flowmeter loggings in four deep supply wells located in the industrial area of Jurubatuba, city of São Paulo. Five fracture sets (G1 through G5) were identified based on OPTV and ATV borehole loggings. The main fracture set (G1), NE-striking with low to intermediate dip, is subparallel to the foliation, being at great extent the result of the reactivation of this previous discontinuity. Fractures on ATV and OPTV images were visually classified with regard to flow evidence, and a positive correlation between high flow evidence and significant flow rate, measured by a flowmeter, was identified. On the other hand, the majority of fractures with insignificant, low or intermediate flow evidence are located in depth intervals with no significant flow rate. Fractures that belong to G1 are of major importance for flow, as in 9 of the 16 intervals with significant flow, they are the only fractures present. Data were inconclusive regarding transmissivity of high dip fractures, because few of them were intercepted by the well boreholes. However, there is evidence that subvertical fractures of sets G3 and G5, NE and NW striking, respectively, are also transmissive, which corroborates outcrop observations. Although geophysical loggings are essential to identify the most important segments of boreholes for water input and output, and to collect detailed data of low dip fracture sets at greater depths, the structural geology characterization of fractured aquifers cannot rely on borehole geophysical loggings alone. For proposing realistic conceptual models of the fracture network, data from boreholes should be complemented with data from large rock exposures (quarries), in order to describe geometrical parameters, such as spacing, length, and physical connectivity of low, intermediate and high dip fractures, as well as evidence of flow along individual fractures.
\end{abstract}

KEYWORDS: Fractured aquifer; geophysical logging; transmissive fractures; hydrogeology.

\section{INTRODUCTION}

The industrial zone of Jurubatuba, located at the southern portion of the city of São Paulo, corresponds to one of the six areas in the state of São Paulo where the groundwater use is restricted (L'Apiccirella 2009), due to the presence of chlorinated solvents in the water of deep supply wells, that extract water from the fractured aquifer (Fig. 1).

Until recently in Brazil, studies on fractured aquifers mostly aimed at the location of new wells and were limited to relate their productivity to morphological, lithological and structural data (Fernandes 2008). About a decade ago,

${ }^{1}$ Centro de Pesquisas de Águas Subterrâneas da Universidade de São Paulo (CEPAS/USP) - São Paulo (SP), Brazil. E-mails: bruna.fiume@ cprm.gov.br, marbbar@usp.br, rhirata@usp.br, bertolo@usp.br

${ }^{2}$ CPRM Serviço Geológico do Brasil - Belo Horizonte (MG), Brazil

${ }^{3}$ Instituto Geológico, Secretaria do Meio Ambiente do Estado de São Paulo - São Paulo (SP), Brazil. E-mail: amelia@sp.gov.br

${ }^{*}$ Corresponding author.

(C) 2020 The authors. This is an open access article distributed under the terms of the Creative Commons license. research has started deploying and integrating a number of methods, such as detailed geological mapping and structural surveys, borehole geophysical loggings, hydraulic tests using straddle packers, as well as chemical and isotopic analysis of water sampled at discrete intervals (Alves 2008, Hart et al. 2007, Fernandes et al. 2011, Wahnfried 2010). Although the use of several methods is essential to identify the preferential flow paths in the complex fractured aquifers, the integration of geophysical logging techniques, such as optical televiewer (OPTV), acoustic televiewer (ATV) and flowmeter in hydrogeological studies is still uncommon in Brazil. In engineering geology, on the other hand, OPTV has been increasingly used for underground works, such as the São Paulo subway (Oliveira et al. 2012).

Internationally, the deployment of logging techniques in hydrogeological studies have been continuously developed both in fractured crystalline aquifers (Paillet and Ollila 1994, Paillet 1995, Stumm et al. 2001, Johnson et al. 2002, Johnson \& Williams 2003, Pino 2012) and sedimentary aquifers (e.g., Morin et al. 1997, 2000, Williams and Paillet 2002). These studies apply, in an integrated manner, both conventional (caliper, 
gamma radiation, resistivity, spontaneous potential, water temperature) and advanced loggings (OPTV and ATV loggings, as well as loggings of flow rate and groundwater direction at specific depth intervals, using flowmeter).

According to Paillet (1995), imaging logs (OPTV and/or ATV) allow the achievement of a detailed structural survey, because they provide precise depths and attitude of planar structures, such as fractures, foliations and bedding. This author has concluded that only few fractures are responsible for the input and output of water flow, and the flowmeter is essential to identify the more transmissive fractures.

The aim of the present work was to integrate the use of conventional and advanced geophysical loggings (caliper, OPTV, ATV, and flowmeter) in order to identify the transmissive fractures in individual wells, drilled in crystalline rocks covered by sediments of the alluvial flat of the Jurubatuba channel (Fig. 1). The collected structural data was compared with the fracture data that resulted from detailed structural surveys conducted in four quarries, located about $20 \mathrm{~km}$ far from the Jurubatuba channel. The quarries are the closest possible to the boreholes, and both are located in the Embu Complex, to the east of the São Paulo Sedimentary Basin (Fig. 1). The structural survey in the quarries was essential, as analysis of subvertical fractures, very frequent in the region, and determination of lengths and fracture interactions are not feasible in boreholes. Besides the comparison of wells and quarries, regional and local lineaments were traced and their trends compared with the direction of the fractures measured in outcrops and wells. The identification of similarities and differences of structural patterns achieved by this joint analysis (lineaments, wells and quarries) aimed at evaluating to what extent the fracture network conceptual model, that resulted from the structural survey in the quarries and previously presented by Fiume (2013) and Fernandes et al. (2016), could be applied to the Jurubatuba area. This application would allow making plausible hypothesis about the contaminant transport, a major concern in the area, and also help interpreting the results of future hydrogeologic and hydrochemical data collection in the area.

\section{METHODS}

This study included local scale lineament analysis, caliper, optical, acoustic and flowmeter geophysical loggings, conducted in four deep supply wells, not to mention the analysis and integration of the data obtained by the loggings. Fracture data achieved by acoustic and optical loggings were compared with the ones collected in big rock exposures (quarries) (Fernandes et al.2016). Local scale lineament tracing and analysis was also conducted in order to obtain a more complete scenario of the

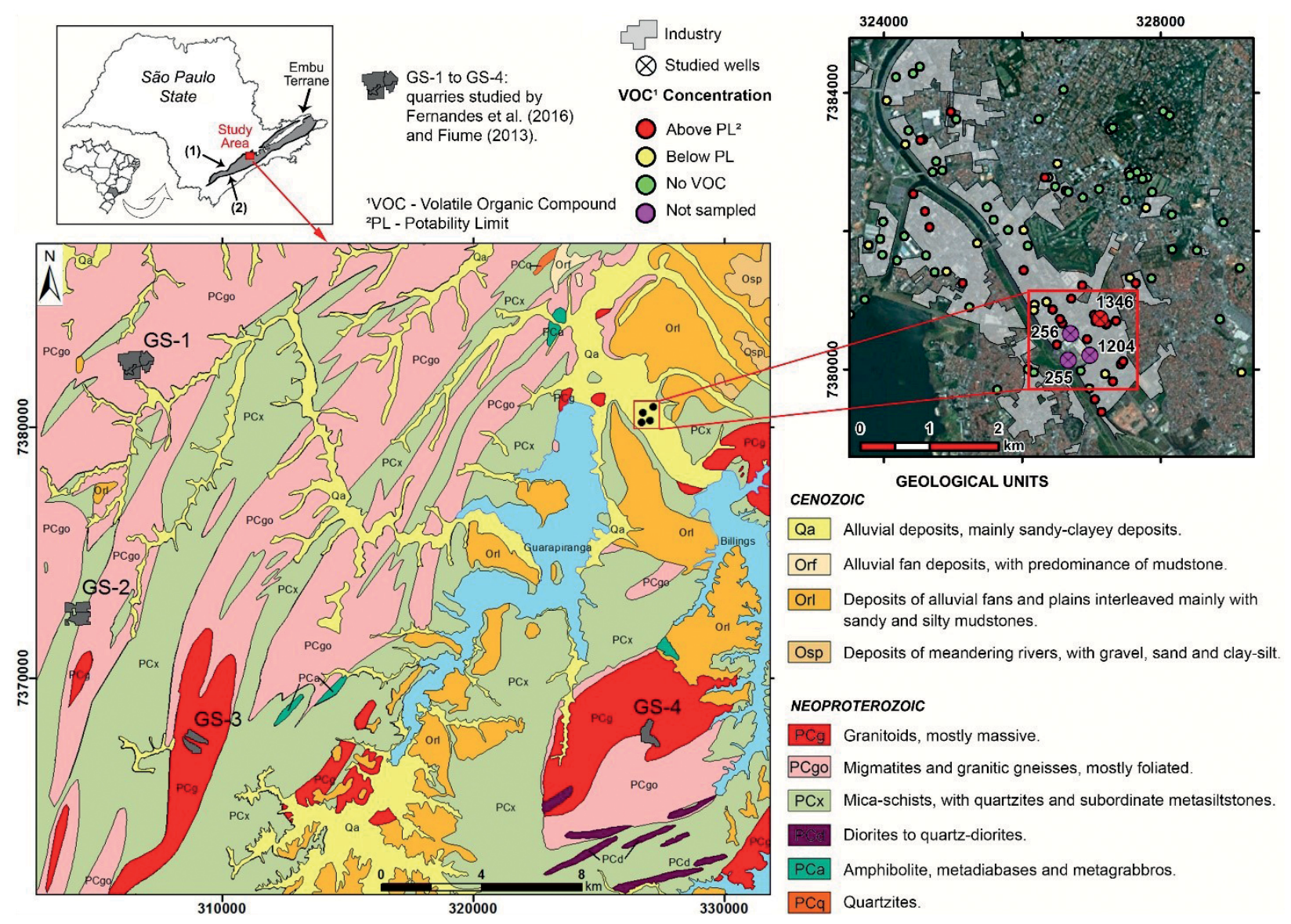

Source: SABESP/CEPAS-IGc-USP (1994).

Figure 1. Geological context and location of the Jurubatuba region, in the city of São Paulo, showing the distribution of concentrations of chlorinated solvents in water of deep supply wells and the identification of wells logged in this study (255, 256, 1204 and 1346). The area of the Embu Terrane (Perrotta et al. 2005) is shown in the map of the state of São Paulo and is delimited to north and south by the Caucaia (1) and Cubatão (2) shear zones, respectively. 
high dip fracture trends, as will be explained later. Figure 2 compares the different methods used.

\section{Analysis of lineaments}

Local scale lineaments were traced on a Digital Terrain Model (DTM) elaborated from 1:10.000 topographic contour maps. Through DIPS 5.1 software, rose diagrams were elaborated for lineament frequency and total length. The local lineament trends were compared with regional ones, available in Fernandes et al. (2005).

The lineament trends were compared with both the fracture set trends obtained from the ATV and OPTV loggings, of the four boreholes, and the ones achieved by fracture surveys at quarries (Fernandes et al.2016, Fiume 2013). This was done in order to evaluate whether lineament analysis can be used for identification and extrapolation of structural domains.

\section{Caliper, optical and acoustic loggings}

In order to obtain the geophysical loggings, four probes were used: the mechanical three-arm caliper probe, attached to a natural gamma radiation logging tool, model I002037 by Robertson Geologging; the OPTV, model I017187 by Robertson Geologging; and the High Resolution Acoustic Televiewer (HRAT), model QL40-ABI-2G by MSI. All probes were connected to a datalogger, using an interface software installed in a computer, so that the logs are displayed in realtime on the computer screen.

The readings were recorded during the probe retraction, at speeds between 1.2 and $1.5 \mathrm{~L} / \mathrm{min}$, starting at the maximum depth of the borehole. The mechanical caliper logging was the first to be conducted in order to identify characteristics such as well casing depth, borehole diameter variations, and the total depth, which was found to differ from the one registered in the well drilling report. An increase in borehole diameter close to rock weaknesses, such as fractures, is common, as a consequence of mechanical breakage caused by the drilling itself (Keys 1979).

OPTV and HRAT loggings resulted in continuous, oriented, flat $360^{\circ}$ images of borehole walls, on which any planar feature is seen as a sine curve, from which the attitude of fractures, foliations, veins, and lithological contacts are obtained (Fig. 3A; Paillet et al. 1990).

The OPTV probe is composed of a ring of LEDs, a camera that can record 60 frames per second, and a hyperbolic or conical receiver in the visible spectrum (Williams and Johnson 2004). True-color images are produced, as in photography, helping to identify lithology, oxidations, precipitations, fracture infillings, among other features.

The HRAT probe emits an ultrasound pulse that is reflected by the borehole walls, generating travel time and amplitude signal responses. The travel time of the acoustic signal is used to calculate the $3 \mathrm{D}$ high-resolution caliper logging (Williams and Johnson 2004).

The OPTV image quality depends on water transparency and, therefore, when there is turbidity, only the HRAT image should be used. On the other hand, wide variations of the borehole diameter affect the tool centralization and, hence, the quality of the acoustic images (Williams and Johnson 2004).

\begin{tabular}{|c|c|c|}
\hline $\begin{array}{c}\text { TOOL } \\
\text { (SCALE) }\end{array}$ & $\begin{array}{l}\text { LOCAL AND REGIONAL } \\
\text { LINEAMENTS }\end{array}$ & $\begin{array}{c}\text { OUTCROPS } \\
\text { (LOCAL SCALE) }\end{array}$ \\
\hline $\begin{array}{l}\text { ㅇ } \\
\text { 옽 } \\
\text { 뽀 }\end{array}$ & $\begin{array}{l}\text { Lineament extraction } \\
\text { from digital elevation } \\
\text { models (regional) and } \\
1.10 .000 \text { topographic map } \\
\text { shaded reliefs (local). }\end{array}$ & $\begin{array}{l}\text { Systematic fracture } \\
\text { survey along horizontal } \\
\text { and vertical scanlines. }\end{array}$ \\
\hline 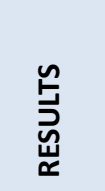 & $\begin{array}{l}\text { Rose diagrams with } \\
\text { the main lineament } \\
\text { trends. } \\
\text { - Structural domains } \\
\text { may be suggested. }\end{array}$ & $\begin{array}{l}\text { Identification of } \\
\text { fracture sets and their } \\
\text { characterization with } \\
\text { regard to attitudes, } \\
\text { spacings, flow } \\
\text { evidence etc. }\end{array}$ \\
\hline ֻั & $\begin{array}{l}\text { - Low time consuming. } \\
\text { Analysis at different } \\
\text { scales, depending on the } \\
\text { available digital terrain } \\
\text { or elevation models. }\end{array}$ & $\begin{array}{l}\text { Diversified scanline } \\
\text { orientations allow bias } \\
\text { avoidance. } \\
\text { - Length, connectivity } \\
\text { and flow evidence are } \\
\text { better characterized } \\
\text { than in the boreholes. }\end{array}$ \\
\hline ֻ & $\begin{array}{l}\text { In areas with rough } \\
\text { relief, only high-angle } \\
\text { fractures are expressed } \\
\text { as lineaments. } \\
\text { - The thick soil of } \\
\text { tropical areas do not } \\
\text { allow correlation of } \\
\text { lineament and fracture } \\
\text { densities. }\end{array}$ & $\begin{array}{l}\text { Appropriate } \\
\text { outcrops may be } \\
\text { available only far } \\
\text { from the areas of } \\
\text { interest. }\end{array}$ \\
\hline
\end{tabular}

\begin{tabular}{|l|l|l|}
\hline \multicolumn{2}{|c|}{$\begin{array}{c}\text { BOREHOLE GEOPHYSICAL LOGGINGS (LOCAL SCALE) } \\
\text { Caliper }\end{array}$} & \multicolumn{1}{c|}{ Optical and Acoustic } \\
\hline $\begin{array}{l}\text { Continuous } \\
\text { measurement of } \\
\text { the borehole } \\
\text { diameter. }\end{array}$ & $\begin{array}{l}\text { Image aquisition of the } \\
\text { borehole walls on which } \\
\text { structure (foliation, fractures } \\
\text { etc) depth and attitudes are } \\
\text { measured. }\end{array}$ & $\begin{array}{l}\text { Measurements } \\
\text { of flow rate at } \\
\text { specific depths } \\
\text { of the borehole. }\end{array}$ \\
\hline
\end{tabular}

- Log of the caliper variation, actual depth of the boreholes and casing conditions.

- Identification and characterization (attitudes, spacing, flow evidence etc) of the fracture sets at an angle greater than $20^{\circ}$ with the borehole.

- Flow rate variation, for adjacent discrete intervals, along the borehole.

- The logs can be compared, and flow evidence related to specific fractures can be reinforced.

- In situ data, and at larger depths, can be obtained.

- Flow direction, water inputs and outputs, and variations in flow rate, are achieved and can be used in conceptual flow models.

$$
\begin{aligned}
& \text { - Boreholes are representative only for low (to medium) dip } \\
& \text { fractures. } \\
& \text { - Fracture length and connectivity are not observable on borehole } \\
& \text { images. } \\
& \text { - Significant flow rate variations cannot usually be assigned to } \\
& \text { specific fractures, as the flowmeter measurements are related to } \\
& \text { depth intervals were several fractures are present. }
\end{aligned}
$$

Figure 2. Comparison between methods used in this study aiming at characterizing the structural framework of fractured aquifers. 
Fractures were classified in terms of flow evidence based on the following features:

- variation in borehole diameter, indicated by acoustic and mechanical calipers;

- thickness of the fracture trace in OPTV and HRAT images;

- presence of weathering indicated by colors such as orange, observed in OPTV logs;

- presence of infilling, which can be observed in the OPTV images.

Based on these parameters, flow evidence along fractures was divided into insignificant, low, intermediate, and high.

In HRAT images, the sine wave fracture trace can appear as a thicker dark band, and this thickness is suggestive of the existence of larger openings and increased flow, but this only a qualitative evidence and not necessarily related to larger apertures (Paillet and Ollila 1994). The total thickness of the dark band (sometimes 10 or more $\mathrm{cm}$ thick) simply shows that the strength of rock, with regard to the drilling process, is lower at that location, due to one or a combination of the following: weathering, presence of closely spaced fractures, and presence of a larger amount of softer minerals (such as mica in schistose bands). The lower strength produces a larger borehole diameter, at that location, and this leads to the darker bands in the HRAT images. For Paillet and Ollila (1994), only 5 to $10 \%$ of the fractures regarded as more transmissive are identified by the flowmeter as hydraulically active fractures. Despite this low correlation, the classification of fractures with regard to flow evidence is considered an important step for optimizing the flowmeter loggings.

\section{Water flow logging: flowmeter}

The Heat Pulse Flowmeter (HPF) measures the axial flow along the borehole at discrete depths, and records the flow rate through the probe in a range from 0.1 to $5 \mathrm{~L} / \mathrm{min}$. In this study, the flowmeter model HFP-2293 by MSI was used. Two procedures for equipment calibration were carried out to ensure the quality of acquired data. The first one was carried out in the laboratory to confirm the quantification limit of the probe informed by the manufacturer. In the second procedure, the null and pumping flow rates were measured in the same segment of the well casing, where no flow exists. The probe operation consists in recording the travel time of a heat pulse generated by an electrical resistance in a pair of thermistors placed above and below the probe (Hess 1986). For the test to provide representative and reliable data, a device named diverter is used to force the water into the probe, for calculating the flow rate by multiplying its internal area by the heat pulse transit velocity. The used diverter is suitable for boreholes of up to $203 \mathrm{~mm}$, however the diameter of some borehole segments were larger, resulting in non-representative data.

Under natural or pumping conditions, water flow in the borehole depends on fracture transmissivities and, in the case of natural conditions, depends also on hydraulic head differences between fractures (Paillet 1995). For most analyses using flowmeter, measurements were carried out under natural and pumping conditions to ensure that all permeable fractures were identified. In pumping conditions, a centrifugal pump was placed some meters below the static water level, regulated at a constant flow rate (between 1 and $4 \mathrm{~L} / \mathrm{min}$ ) and monitored, so that the measurements would start when the water level was stabilized.

Segments to be tested were selected based on the classification of fractures with regard to flow evidence, as described above. For each depth, at least three readings were conducted for checking result reproducibility. Next, the discrepancies were discarded, and the arithmetic mean of the flow rate was calculated. Flow rate ranges were classified as insignificant, low,

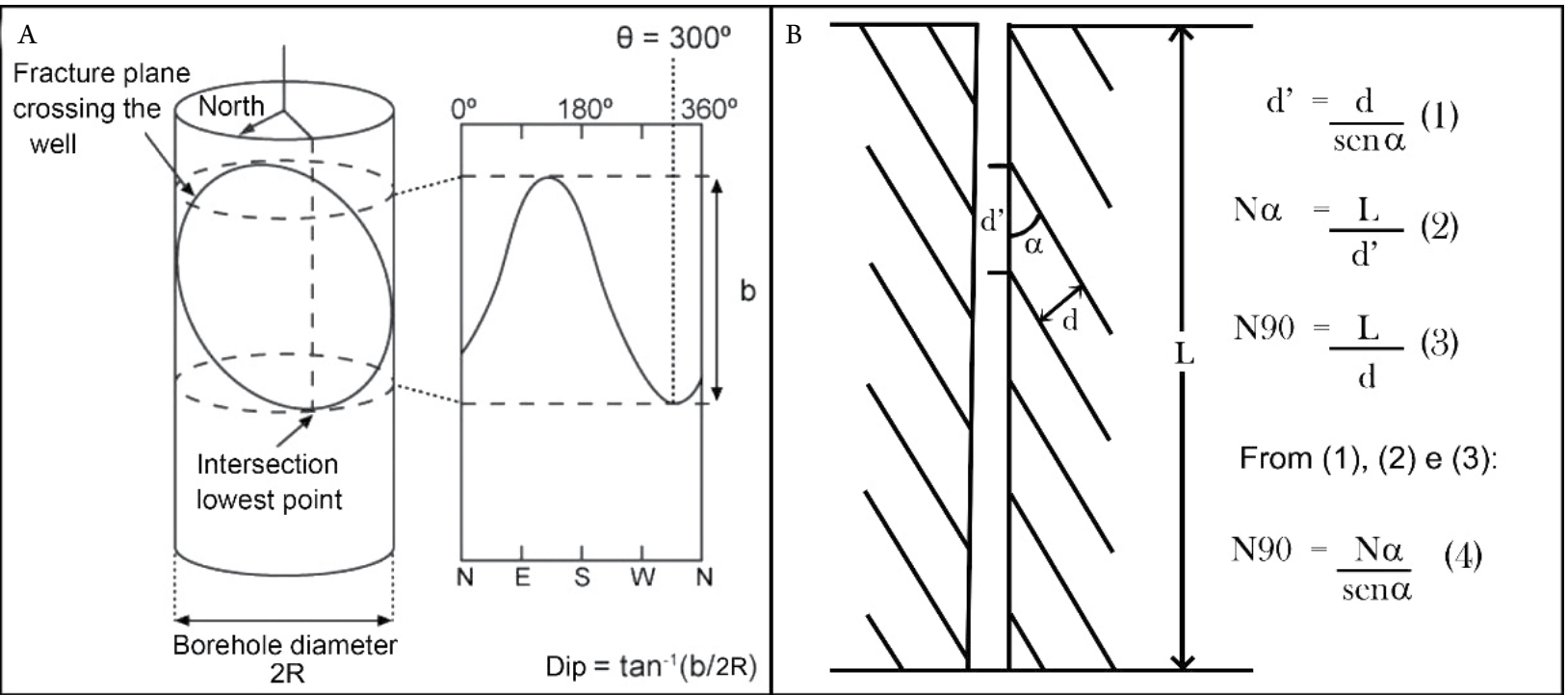

$\alpha$ : angle between the borehole and the fracture; L: well depth; N $\alpha$ : apparent fracture density; N90 corrected fracture density.

Figure 3. (A) Representation of the fracture that intercepts a borehole in the form of a sine wave due to planar projection of the borehole wall, determining the dip direction $(\theta)$ and its dip, a function of b and $d$ (adapted from Paillet 1994). (B) Illustration of the angular relationship between apparent (d') and corrected (d) spacing of fractures of the same group, and the calculation of the fracture density correction (modified from Terzaghi 1965). 
intermediate, and high, whose limits were established based on natural breakages observed in cumulative frequency diagrams.

\section{Processing and integration of logging data}

Data obtained by loggings were processed using WELLCAD v.4.4 software. Fracture attitudes, identified in OPTV and HRAT images, were corrected for magnetic declination and caliper variation. Fractures were plotted on stereonets using DIPs software.

Terzaghi's method (1965) was used in order to correct the sampling bias due to the value of the angle between the fracture and the well; the high-dip fractures are the most undersampled in vertical boreholes. The method is based on the relationship between apparent (d') and true (d) spacing for each fracture set, which is determined by the angle $(\alpha)$ between the borehole and the intercepted fracture (Fig. 3B). Therefore, the number of fractures that would be intercepted (N90), if a borehole with a length $\mathrm{L}$ was drilled perpendicular to the fractures, is obtained assigning a weight of $1 / \sin \alpha$ to the number of fractures present $(\mathrm{N} \alpha)$, as indicated in Equation 2 (Fig. 3B). Terzaghi (1965) recommends to disregard fractures that form an angle $\alpha$ smaller than $20^{\circ}$, in order to avoid large errors that can arise from this correction. This study deployed the adaptation of the Terzaghi method (1965) by Pino (2012), in order to obtain corrected contour densities on stereonets by using software. Densities were calculated similarly for fractures with $\alpha$ greater than $20^{\circ}$ for each borehole, adding the $1 / \sin \alpha$ weight attributed to each fracture of the same group and dividing the total by the logged segment; spacing corresponds to the inverse of density.

The observation of caliper, flow rate, and tadpole logs, side by side, allow a synoptic view of data. A tadpole represents a fracture as a point (dip) and an adjacent trace (dip direction). There are two tadpole logs for each borehole: one shows the classification of fractures as parallel or non-parallel to the foliation; the other classifies the fractures with regard to flow evidence (FE).

\section{RESULTS}

\section{Regional and local lineaments}

Regional lineament trends, seen in rose-diagrams (Fig. 4), were compared with the trends of fractures measured in quarries and presented in Fiume (2013) and Fernandes et al. (2016). Only fractures dipping more than $60^{\circ}$ were represented in rose diagrams, since only high-dip fractures can be observed as lineaments on the surface and, therefore, a direct comparison of fractures and lineaments can be made. Both exhibit the trends N20-50W, N80-90W, N60-90E (Tab. 1), however the trend N10W-N10E is present only in the lineaments. The trend $\mathrm{N} 20-40 \mathrm{E}$ is prominent in the regional lineaments rose diagram, but almost absent in the fracture rose-diagram. This is probably due to the fact that three of the outcrops are massive granites, where the NE striking regional foliation, of the metamorphic rocks, is absent. Only one outcrop, Embu quarry, is composed of gneiss, being similar to the rocks at Jurubatuba site. This foliation, regional shear zones of the same direction, and fractures that are the product of the reactivation of those structures, give rise to the NE lineament trend.

The local lineament map contains the area where the logged boreholes are located, close to Jurubatuba channel, and their directions were compared to the fracture trends observed in the boreholes. The most important difference is that while the $\mathrm{N}-\mathrm{S}$ trend predominates in the lineament rose diagram, the N60-90E and N80-90W high dip fracture trends are more frequent in boreholes. Although N20-50W trend is almost absent in boreholes, it is conspicuous in outcrops and regional lineaments. Due to the undersampling of high dip fractures in vertical boreholes, significant differences between lineaments and outcrop fractures, on one side, and boreholes, on the other, are to be expected. An overall conclusion is that almost all trends can be observed at local and regional scales and, therefore, they should be represented in conceptual models. Furthermore, the characterization of high dip fracture trends depends on the description of outcrops. The prominence of trend NS in regional and local lineaments, although secondary in outcrops, suggests that this direction might have been relatively active in recent periods. Such activity would affect river courses, and, as a consequence, would highlight the NS lineaments. NS trend may be partially the result of the preferential reactivation of NNW direction, which is part of the direction range of the NW trend, as described in the section "Fracture sets".

\section{Local geology}

The OPTV images, unless when the borehole wall was oxidized, allowed the description of the lithology in the study area (Fig. 5) and the measurement of the foliation. Fine-grained gneiss rich in mafic minerals, migmatite with lens-shaped layers of felsic minerals intermingled with darker parts with fine granulation, pegmatites, schists interleaved with fine-grained gneisses are present in the area. The thickness of gneissic and pegmatitic bands are mostly centimetric and decimetric, respectively. The site is located in the PCx (schist) unit, which is very subordinate in the wells. This inconsistency probably arose from the fact that the site is quite small when compared to the map scale (1:100.000).

Foliation, banding, and lithology contact directions are approximately N40-50E; however, the geological map, outcrops and boreholes show that the foliation attitude is variable (Fig. 5), indicating that folds are quite frequent, some of them observed in rock exposures.

\section{Fracture sets}

Five fracture sets were identified in OPTV and HRAT images of wells 255, 256, 1204 and 1346. They were named G1 to G5, being the fractures of G1 by far the most frequent (Tab. 2A). OPTV images were severely oxidized after a certain depth of the boreholes. Under these conditions, HRAT images were essential to identify fractures.

Fracture set G1 is present in all wells and, in general, parallel to the foliation. Due to sampling bias, 82 to $95 \%$ of the fractures belong to this set (Tab. 2B), as it is the only one in 


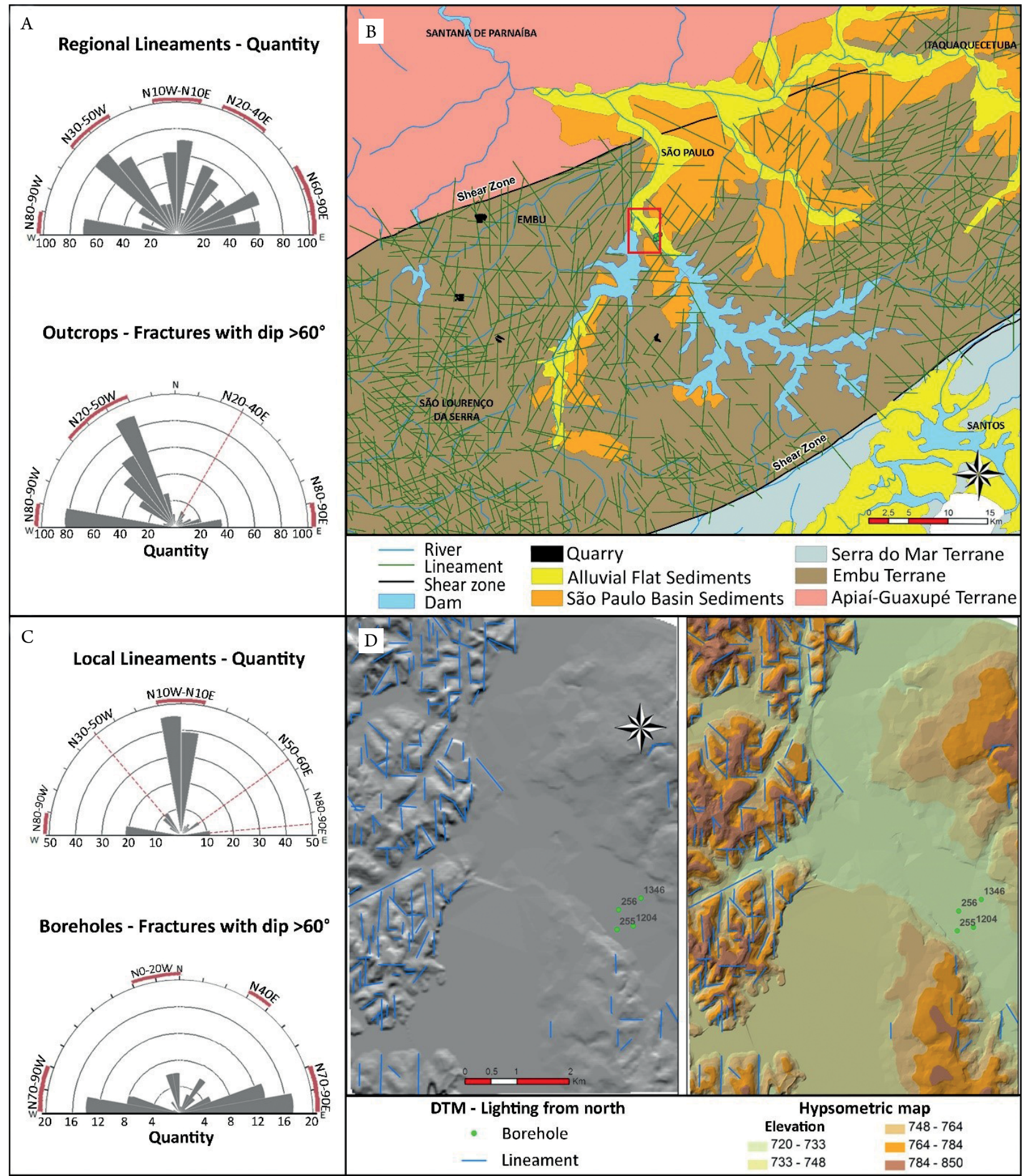

Figure 4. (A, B) Regional and (C, D) local lineaments (elaborated by Fernandes et al. 2005; and Fiume 2013, respectively) and their respective frequency and length rose diagrams, as well as frequency rose diagram, for fractures with dip higher than $60^{\circ}$, obtained from outcrops (Fiume 2013, Fernandes et al. 2016) and logged boreholes.

Table 1. Comparison between lineaments and fractures, with dip greater than $60^{\circ}$, measured in outcrops and boreholes. The direction ranges are illustrated in the rose diagrams of Figure 4 . The symbol ">>" means much greater abundance.

\begin{tabular}{lccccc}
\hline \multirow{2}{*}{ Trend } & \multicolumn{2}{c}{ Strike } & & \multicolumn{2}{c}{ Strike } \\
\cline { 2 - 3 } \cline { 5 - 6 } \cline { 5 - 6 } NW & Regional lineaments & Fractures in outcrops & & Local lineaments & Fractures in boreholes \\
EW-WNW & N30-50W & N80 N20-50W & & N30-50W & N80-90W \\
ENE & $>>$ N60-90E & N80-90E & & N80-90E & absent \\
NE & N20-40E & N20-40E & & N50-60E & $>$ N70-90W \\
NS & N10W-N10E & absent & & $>>$ N10W-N10E & N40E \\
\hline
\end{tabular}



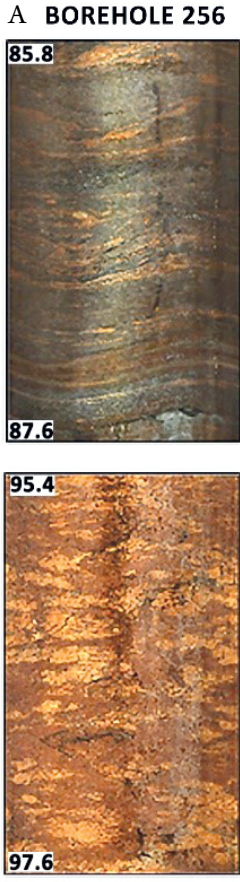

Legend

- Borehole

85.8 Depth in meter

For geological legend, see Figure 2.

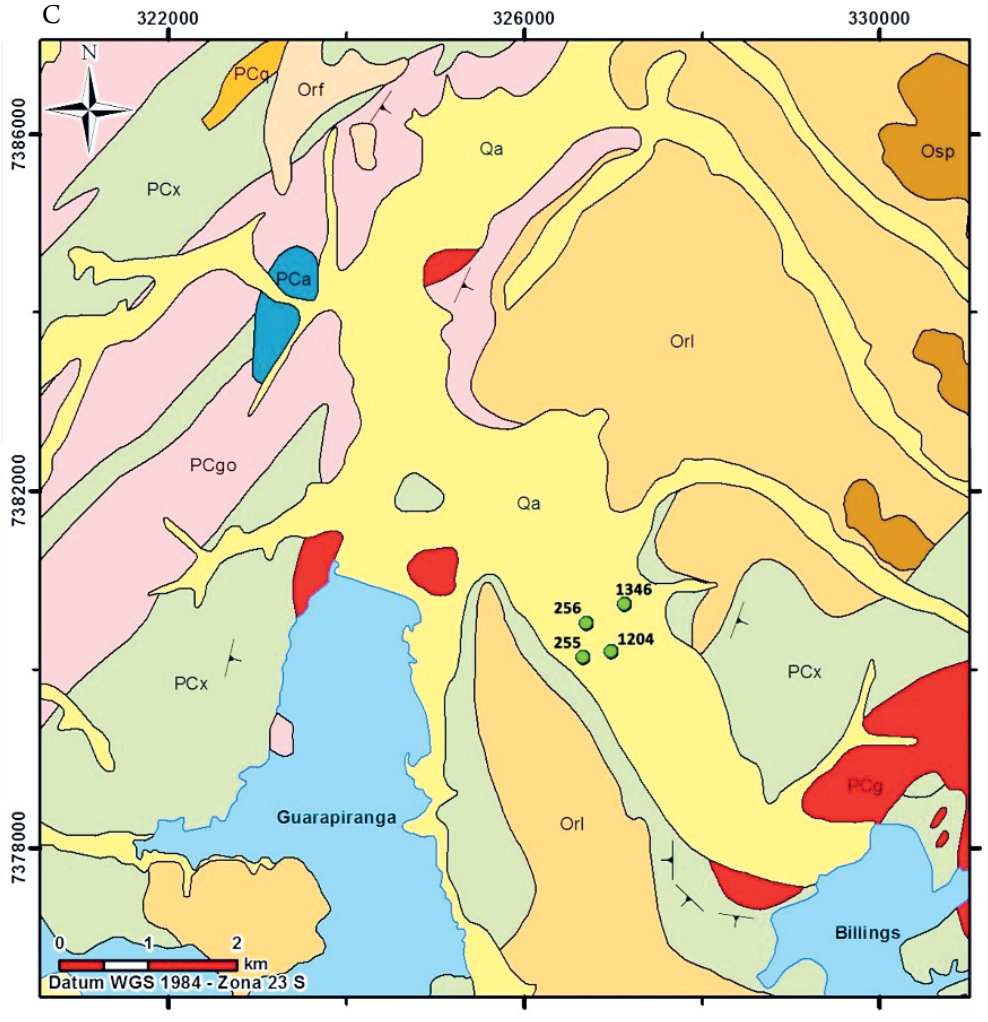

Figure 5. Optical televiewer (OPTV) images of wells (A) 256 and (B) 1204. In (A) well 256, the segment starting at $85.8 \mathrm{~m}$ contains a fine-grained mesocratic gneiss; at $95.4 \mathrm{~m}$, there is a migmatite with lens-shaped felsic bands and intrafoliation folds. In (B) well 1204, the segment starting at $97.3 \mathrm{~m}$ is a fine-grained leucocratic gneiss with the intercalation of a felsic pegmatite, and at $113.2 \mathrm{~m}$, fine-grained gneisses intercalate felsic bands and schists (darker portions). Close to Represa Billings the variation of the foliation attitude demonstrates the presence of folds. For legend of geological units (SABESP/CEPAS-IGc-USP 1994), see Figure 1.

Table 2A. Fracture sets identified on optical televiewer (OPTV) and High Resolution Acoustic Televiewer (HRAT) loggings. Spacings of fractures in quarries are those presented by Fernandes et al. (2016).

\begin{tabular}{|c|c|c|c|c|c|c|c|}
\hline $\begin{array}{l}\text { Fracture set } \\
\text { (total amount } \\
\text { of fractures) }\end{array}$ & $\begin{array}{l}\text { General } \\
\text { attitude }\end{array}$ & Well & Strike range & Dip & Quantity & $\begin{array}{c}\text { Spacing in } \\
\text { boreholes (m) }\end{array}$ & $\begin{array}{c}\text { Spacing in } \\
\text { quarries }(\mathbf{m})\end{array}$ \\
\hline \multirow{4}{*}{ G1 (1048) } & & 255 & $\mathrm{NE}$ & $0-50^{\circ} \mathrm{NW}$ & 262 & 0.6 & \multirow{4}{*}{2} \\
\hline & & 256 & NE (NW-NS) & $20-60^{\circ} \mathrm{SE}, \mathrm{NW}$ & 123 & 0.9 & \\
\hline & & 1204 & $\mathrm{NE}(\mathrm{NW})$ & $0-50^{\circ} \mathrm{NW}, \mathrm{SE}$ & 267 & 0.7 & \\
\hline & & 1346 & $\mathrm{NE}(\mathrm{NW})$ & $10-60^{\circ} \mathrm{NW}, \mathrm{SE}$ & 115 & 0.8 & \\
\hline \multirow{4}{*}{ G2 (42) } & \multirow{4}{*}{$\mathrm{E}-\mathrm{W},>60^{\circ}$} & 255 & N70-90E N80-90W & $67-83^{\circ} \mathrm{N}$ & 25 & 1.6 & \multirow{4}{*}{$\begin{array}{c}1.5 \text { to } 32 \\
(\mathrm{ZFs}-0.2 \text { to } 0.8)\end{array}$} \\
\hline & & 256 & N70-90E & $76-87^{\circ} \mathrm{NNW}$ & 5 & 4.1 & \\
\hline & & 1204 & N70-90W & $58-80^{\circ} \mathrm{NNE}$ & 5 & 12.7 & \\
\hline & & 1346 & N60-80E & $64-80^{\circ} \mathrm{NW}$ & 7 & 4.1 & \\
\hline G3 (37) & $\mathrm{NE},>60^{\circ}$ & 1204 & N20-50E & $61-69^{\circ} \mathrm{SE}$ & 10 & 8.7 & $>28$ \\
\hline \multirow[b]{2}{*}{ G4 (33) } & & 256 & N60-80W & $52-68^{\circ} \mathrm{SW}$ & 9 & 9.0 & \multirow[b]{2}{*}{3.7 to 37} \\
\hline & $\mathrm{E}-\mathrm{W}, 45$ to $65^{\circ}$ & 1204 & $\begin{array}{l}\text { N75-90E } \\
\text { N75-90W }\end{array}$ & $47-66^{\circ} \mathrm{S}$ & 14 & 7.4 & \\
\hline G5 (25) & $\mathrm{NNW},>60^{\circ}$ & 1204 & N0-15W & $62-83^{\circ} \mathrm{ENE}$ & 12 & 4 & $\begin{array}{c}2.4 \text { to } 13.8 \\
\text { (ZFs }-0.1 \text { to } 0.5)\end{array}$ \\
\hline
\end{tabular}

Esp: spacing; ZFs: fracture zones; G1: predominantly subhorizontal to low angle dips, NE general direction and NW for the lower dips, it is usually subparallel to the foliation; G2: EW, subvertical to high dips; G3: NE, intermediate to high dips either towards NW or SE; G4: EW, intermediate dips to south; G5: NW-NNW with high or subvertical dips towards NE or SW.

Table 2B. Quantity of fractures in wells, and the fractures sets (G1 to G5, see Fig. 6) to which they belong.

\begin{tabular}{lccccccc}
\hline & $\begin{array}{c}\text { Total of } \\
\text { fractures in well }\end{array}$ & $\begin{array}{c}\text { Logged interval } \\
(\mathbf{m})\end{array}$ & G1 & G2 & G3 & G4 & G5 \\
\hline 255 & 294 & 187 & $\mathbf{8 9 \%}$ & $9 \%$ & 0 & $2 \%$ & $0,7 \%$ \\
256 & 142 & 154 & $\mathbf{8 5} \%$ & $3 \%$ & 0 & $6 \%$ & 0 \\
1204 & 313 & 204 & $\mathbf{8 2} \%$ & $1.5 \%$ & $4 \%$ & $4 \%$ & $4 \%$ \\
1346 & 153 & 113 & $\mathbf{9 5} \%$ & $5 \%$ & 0 & 0 & 0 \\
\hline
\end{tabular}


which low dips predominate. The foliation is affected by asymmetric folds with NE axis (Fig. 6), which is demonstrated by the distribution of its poles along great circles. This distribution is mimicked by the poles of G1 fractures, as these are mostly related to the reactivation of the foliation. G1 fractures are mostly NE striking (or NW for the lower dips) and the dip usually ranges from 10 to $40^{\circ}$. The folds affecting the foliation are more evident in wells 255 and 1204, being very similar to the one identified in the Embu quarry (Fig. 6F) by Fernandes et al. (2016), where a granitic gneiss, with subordinate schist intercalations, crop out. In wells 256 and 1346, in addition to great circles related to folds with NE axis, there is also dispersion of poles along NS direction, suggesting folds with EW striking axis.

Fracture sets $\mathrm{G} 2$ to $\mathrm{G} 5$ are correlated to the sets identified by Fernandes et al. (2016) in quarries (Fig. 6F); the three fracture sets with dips greater than $60^{\circ}$ (EW, N20-50E, and NNW directions) in the boreholes (Tab. 2A) are subvertical in the outcrops (Fig. 6F). G5 fracture set, in quarries, is subvertical and N10-70W striking (e.g., Fig. 6F), however, in the wells, only the NNW direction is observed. Although the vertical boreholes do not allow the estimation of representative spacings of subvertical fractures, the well fracture stereograms in Figure 6 show that it is possible to identify high dip fracture sets, and not only compare them with the ones characterized in outcrops but also correlate them with lineament trends (Fig. 4).

The spacing of $\mathrm{G} 1$ is almost constant in the four wells, ranging from 0,6 to $0,9 \mathrm{~m}$. G2 (EW striking, dip $>60^{\circ}$ towards North), with spacings ranging from 1.6 to $12.7 \mathrm{~m}$, is the only set, with high dips, that is observed in the four wells, which reinforces the importance of the EW direction, the second most frequent trend of the local lineaments (Fig. 4C). G4 (EW striking, dip $>60^{\circ}$ towards South) is intercepted by two wells (256 and 1024), with average spacings of 9 and $14 \mathrm{~m}$. However, it is absent in two wells, implying that larger spacings also exist; it suggests a bimodal spacing for G54. There is little information for G3 (N20-50E striking, $>60^{\circ}$ towards SE) and G5 (NNW striking, dip $>60^{\circ}$ towards ENE), as they are present only in well 1204, with average spacings of 4 and $8.7 \mathrm{~m}$, respectively. However, G3 and G5 are absent in 3 wells, and similarly to G4, the spacings may be much larger. Due to sampling bias, results obtained for G2, G3, G4 and G5 are not representative, however all of them are important fracture sets in the quarries. Besides this similarity, it is worth noticing that de low dip fractures, which parallel to the foliation, mimic folds that affect the foliation, being mostly distributed along a NE trending great circle, in both wells and quarries. All these similarities, along with the lineament analysis, indicate that the conceptual geometric fracture model presented by Fernandes et al. (2016) and built based on fracture surveys carried out at rock exposures, is a reasonable first approximation to the study area. The drilling of inclined wells should be considered as an important step for a better characterization of the subvertical fractures the Jurubatuba area.

In this way, for this study, it was found that surveys in outcrops and boreholes provide complementary data. Fracture data from rock exposures provide end-members of the spacings for all fracture sets. Boreholes, on the other hand, allow a representative sampling of subhorizontal and low dip fractures at greater depths, as the quarry expositions are up to about $100 \mathrm{~m}$ deep, and the logged boreholes maximum depths range from 140 up to $313 \mathrm{~m}$.

\section{Flow rates and transmissive fractures}

The OPTV and HRAT loggings allowed the classification of each fracture with regard to being parallel or non-parallel to the foliation, as well as with respect to the flow evidence (FE) as follows: insignificant-FE, intermediate-FE, low-FE, and high-FE. These classifications, along with caliper logs, obtained from ATV, and flow rate, obtained from heat-pulse flow meter (HPFM), are shown in Figures 7 to 10. OPTV images and polar stereonets, of some of the depth intervals with larger flow rates, are also shown. The OPTV image could be orange (Figs. 7, 9 and 10) either at shallow depths, due to oxidation that took place while the well was being pumped and the water level was lowered, or at deep stretches of the wells, probably due to water turbidity.

The HPFM measurements obtained, under natural and pumping conditions, were compared in order to interpret the well flow and identify the hydraulically active zones. Flowmeter readings are represented by squares and flow interpretation by lines (Figs. 7 to 10). At some depths, such as 30 to $75 \mathrm{~m}$ of well 255,145 to $155 \mathrm{~m}$ of well $256,125 \mathrm{~m}$ of well 1204 , and $93 \mathrm{~m}$ in well 1346, the values obtained with the flowmeter showed inconsistencies. For example, upward decrease in flow measurements are not expected under pumping conditions, as the ascending flow prevents the existence of water outlets. It is considered that the remarkable variations of the drilling diameter and irregularities of the borehole wall, precisely at those depth intervals, caused the loss of efficiency in the HPFM diverter (the pumped water passes mostly between the diverter and the borehole wall) and, consequently, the inconsistent flow measurements. Such situations are indicated in Figures 7 and 8 as "loss of efficiency". Paillet (2004), who describes the most common problems that occur in HPFM tests, as well as the adjustment and data processing procedures, was used as the basis for these interpretations.

The flow rate variation (dQ), calculated for specific depth intervals, from the flowmeter measurements, was classified as: insignificant $(<0.2 \mathrm{~L} / \mathrm{min})$, low $(0.2$ to $0.5 \mathrm{~L} / \mathrm{min})$, medium $(0,6$ to $2.0 \mathrm{~L} / \mathrm{min})$, and high $(>2.0 \mathrm{~L} / \mathrm{min})$. Significant flow rate variation $(\mathrm{dQ}>=0.2 \mathrm{~L} / \mathrm{min})$ was identified in 13 depth intervals (Tab. 3), 8 of these identified only under pumping conditions. This is the case of the hydraulically active zones of well 1346, where the natural flow was null. Downward natural flow, of the order of $0.6 \mathrm{~L} / \mathrm{min}$ and $1.7 \mathrm{~L} / \mathrm{min}$, was observed in wells 256 and 1204, respectively; no measurable natural flow was identified in wells 255 and 1346. Higher flow rates predominate in well 1204 ( 2 intervals each, and intermediate dQ in wells 255, 256, and 1346). Note that dQ is not controlled by the depth.

The length of the 13 depth intervals, with significant dQ, varies from 2 to $16 \mathrm{~m}$, each containing a variable amount of 


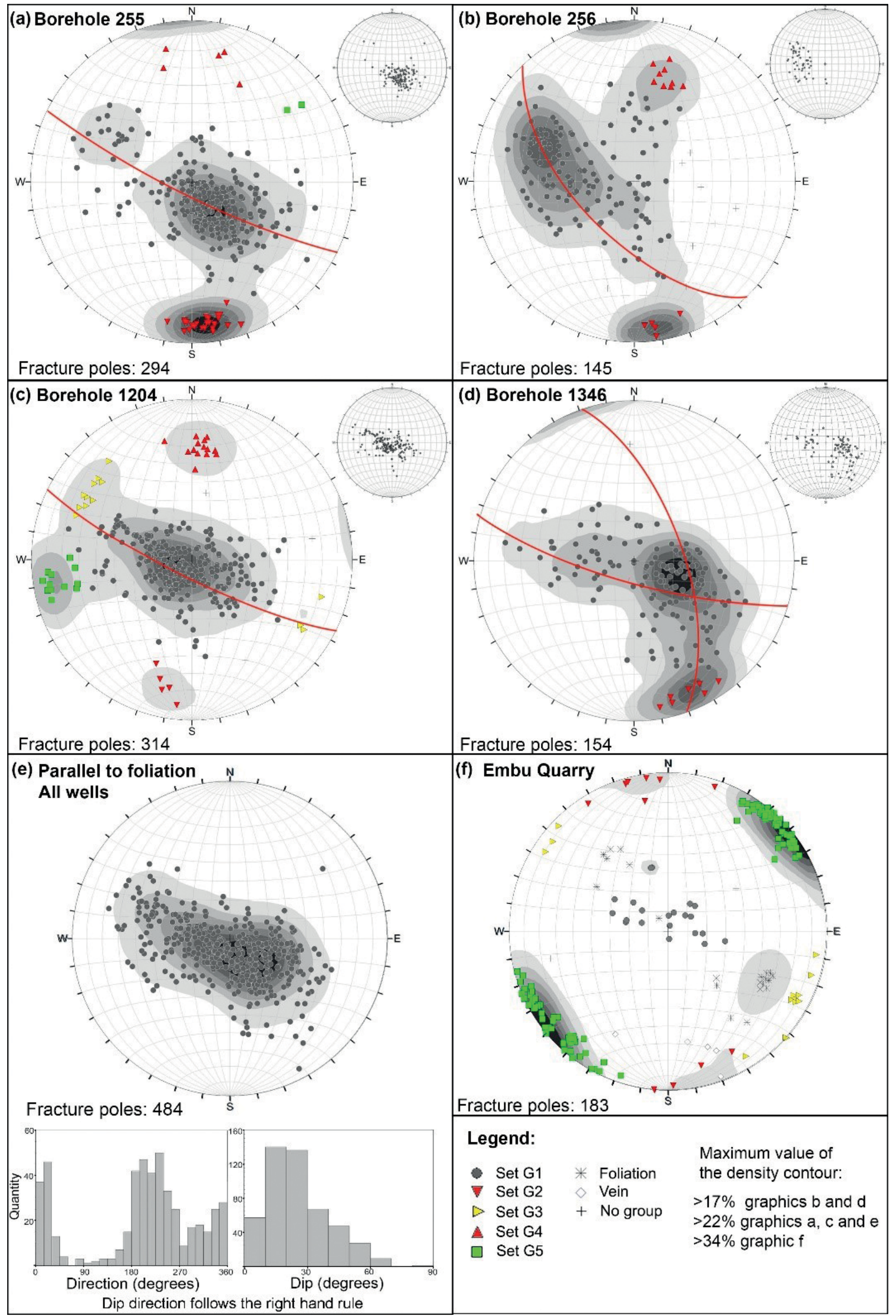

Figure 6. Polar stereonets for fractures, and density contours, of wells (A) 255, (B) 256, (C) 1204, and (D) 1346. Each smaller stereonet at the top-right corners shows only the fractures that are parallel to the foliation. (E) Poles of fractures G1, which are parallel to the foliation, draw a large circle in each well, which is indicative of the existence of cylindrical folds, with subhorizontal NE axis, affecting the foliation; histograms show direction (right hand rule) and dip of the G1 fractures total amount. (F) Poles of fractures parallel to the foliation of the gneiss in Embu Quarry (Fernandes et al. 2016) draw large circles similar to the ones in the boreholes. 


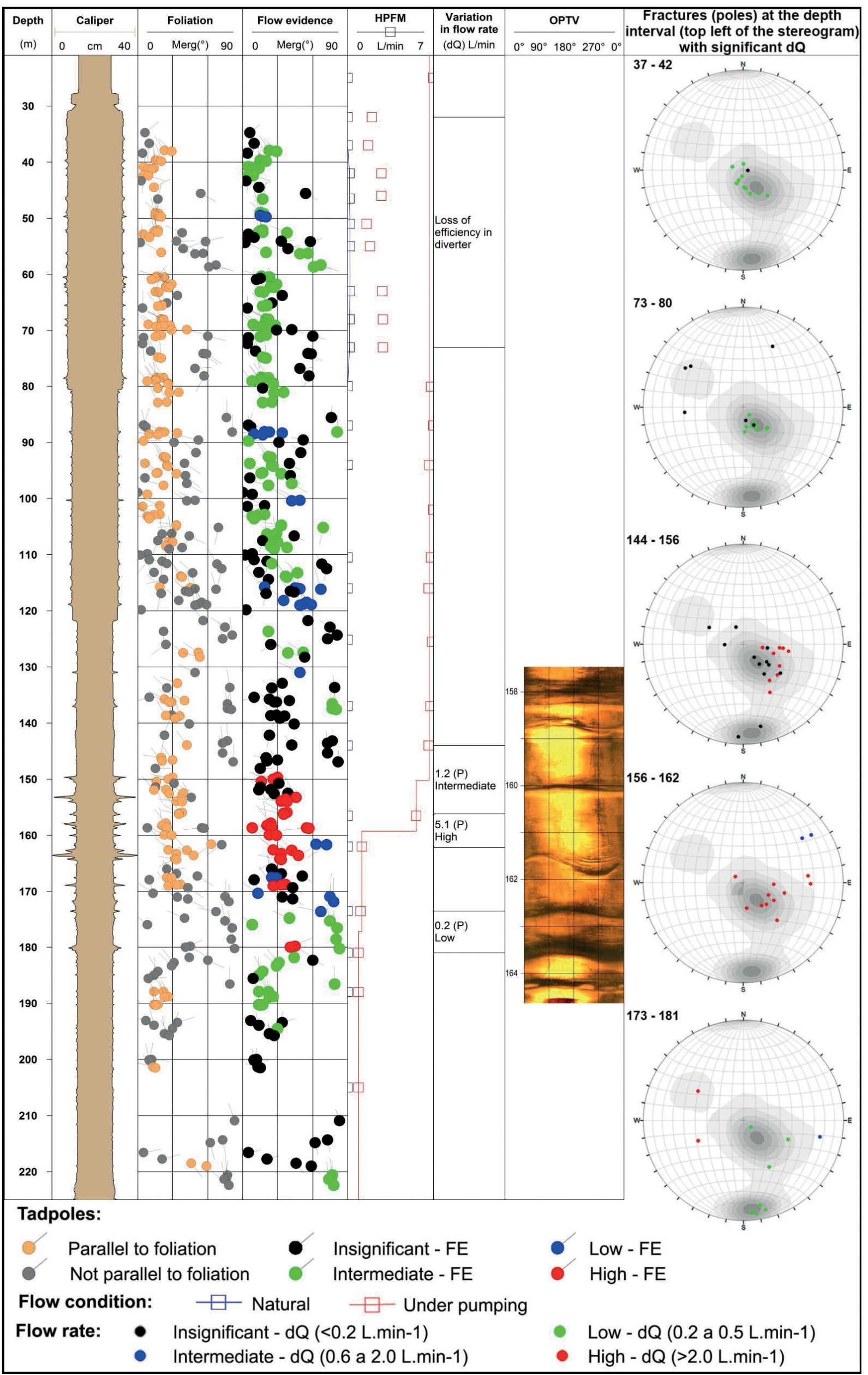

FE: flow evidence; HPFM: heat-pulse flow meter; dQ: flow rate variation.

Figure 7. Integrated loggings of well 255. The optical televiewer (OPTV) image illustrates the high-FE fractures of interval $156-164$. 


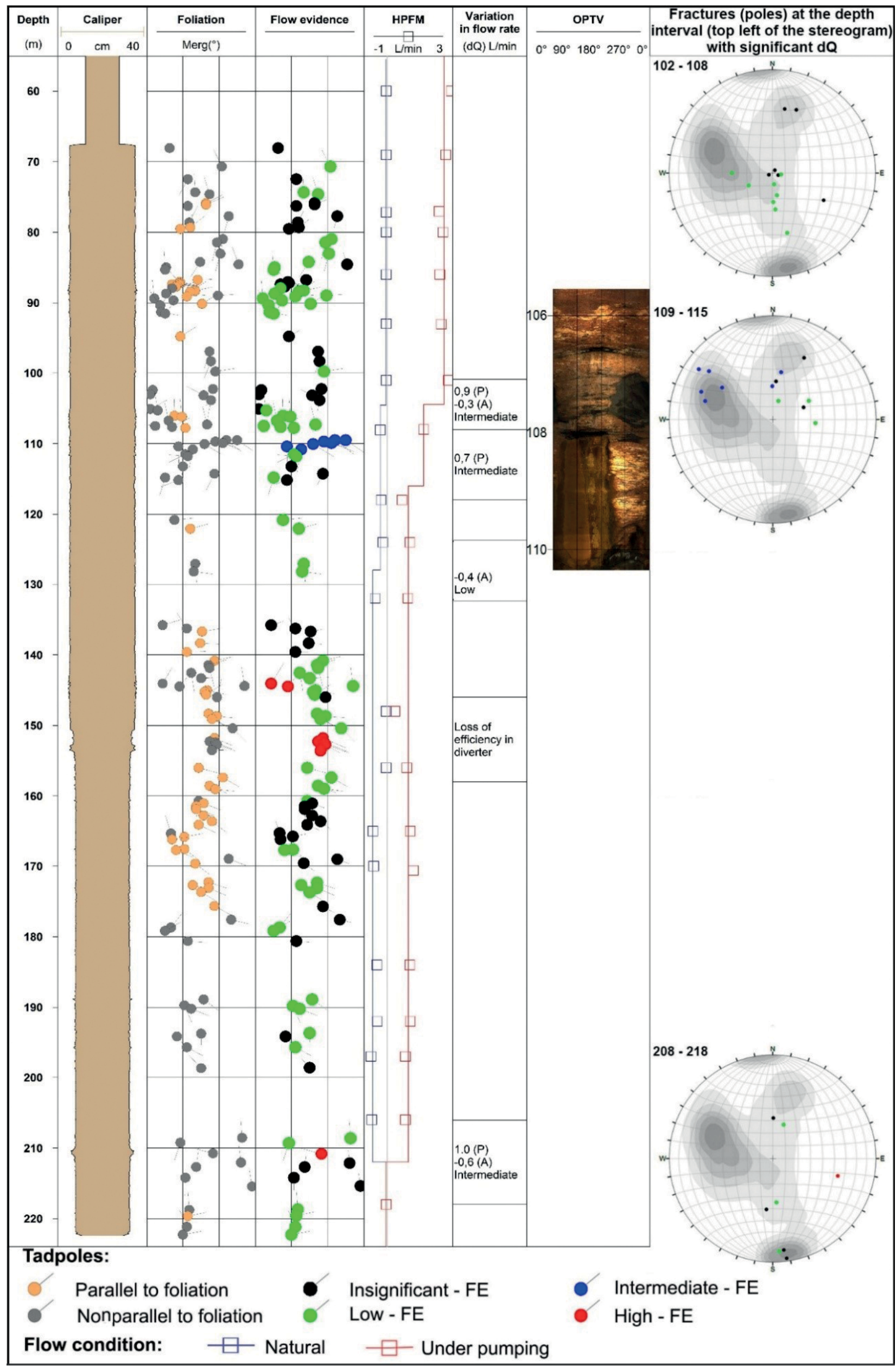

FE: flow evidence; HPFM: heat-pulse flow meter; OPTV: optical televiewer; dQ: flow rate variation.

Figure 8. Integrated loggings of well 256. 


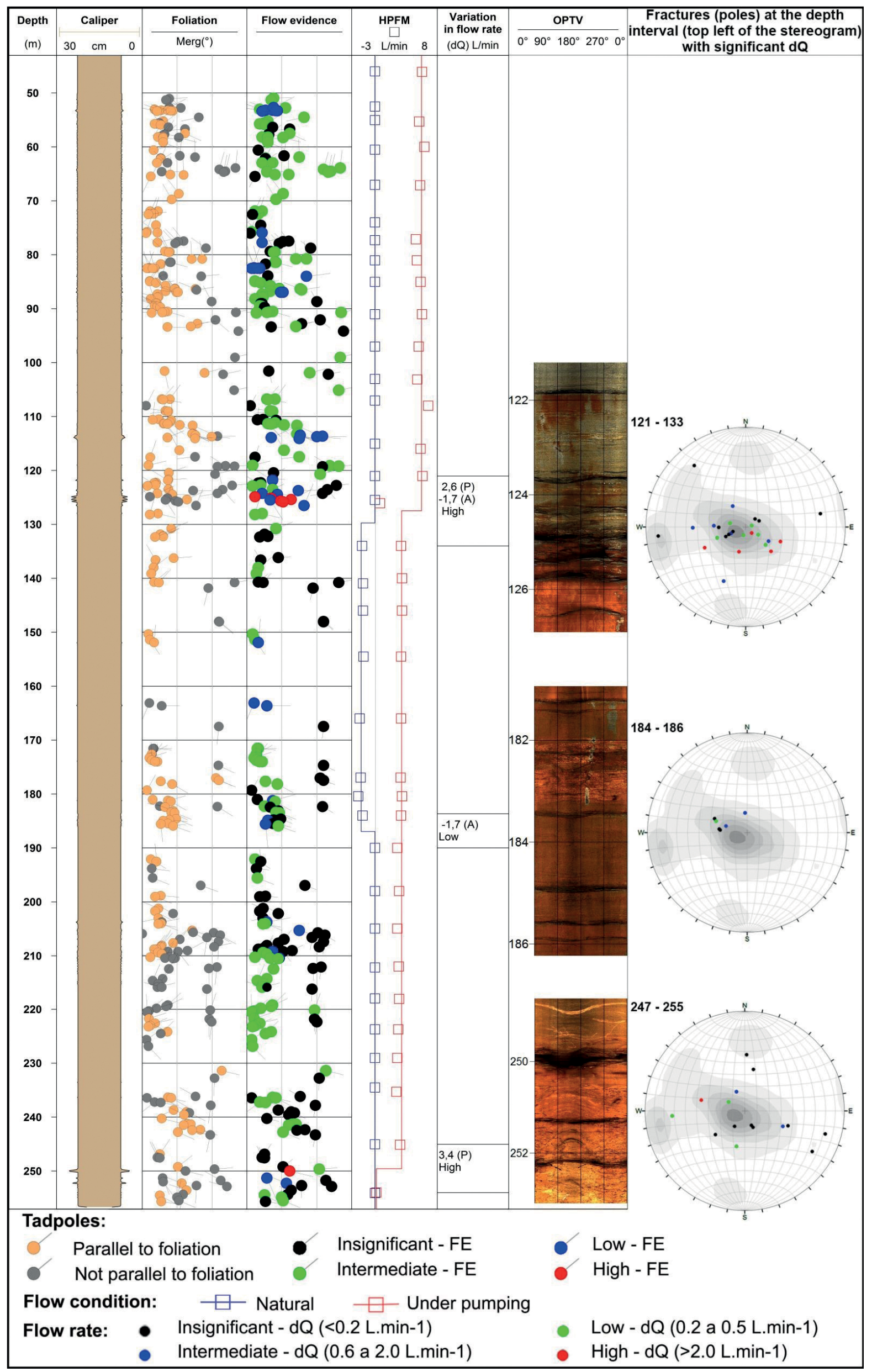

FE: flow evidence; HPFM: heat-pulse flow meter; dQ: flow rate variation.

Figure 9. Integrated loggings of well 1204. The optical televiewer (OPTV) images illustrate the high-FE and intermediate-FE fractures of 3 high-dQintervals. 


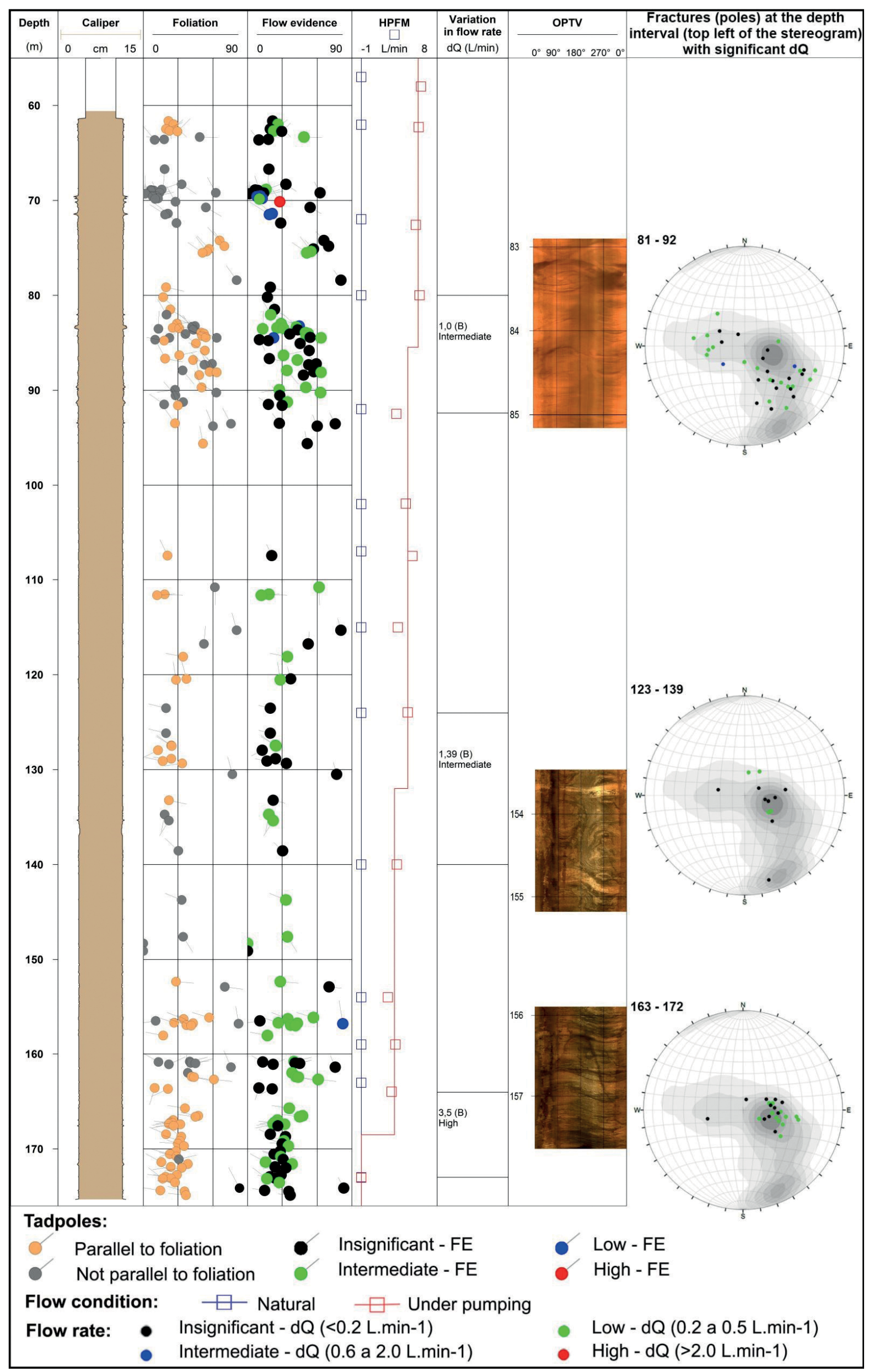

FE: flow evidence; HPFM: heat-pulse flow meter; flow rate variation.

Figure 10. Integrated loggings of well 1346. The optical televiewer (OPTV) image at shallower depths is very oxidized and the classification of fractures was more difficult. The image at greater depths illustrates a high dip, intermediate-FE fracture cutting the foliation of the gneiss. 
fractures (since 6 up to 36) that belong to different classes of flow evidence (Tab. 3, Figs. 7 to 10). All 13 intervals but one contain G1 fractures, which are largely predominant, due to the sampling bias along the vertical boreholes. The direction of these fractures, in the intervals with significant $\mathrm{dQ}$, spreads through all the NE quadrant, ranging from N60-90E (255 in $75 \mathrm{~m}, 256$ in $\sim 106 \mathrm{~m})$ to N15E (256 in $\sim 210 \mathrm{~m})$. Although not as frequent, subhorizontal NW striking fractures belonging to G1 are more frequent at well 1204. G1 dips towards NW (slightly predominant) or SE, varying from subhorizontal (mainly at well 1204) up to $55^{\circ}$.

In 4 of the 10 intervals, with intermediate or high $\mathrm{dQ}_{2}$ at least part of the G1 fractures belong to high and/or intermediate flow evidence classes; in 4 of the remaining intervals, G1 fractures belong to low-FE and insignificant-FE classes (Tab. 3, Figs. 7 to 10). Therefore, these numbers show that the correlation between significant $\mathrm{dQ}$, from low to high, and fractures of high to intermediate-FE classes is not clear. It suggests that the visual classification of the flow evidence is not as effective in order to identify transmissive fractures, and that low-FE fractures (and even the insignificant-FE ones) cannot be considered, a priori, as non-transmissive. The analysis of the validity of the visual classification of fractures with regard to the flow is made difficult by the fact that in each interval, with significant $\mathrm{dQ}$, it is not possible to identify, among the several fractures that are present, which are responsible for the measured flow. Besides, other factors than larger apertures of individual fractures are also likely to play a role to raise the transmissivity of a specific interval. For example: a larger number of fractures with low but significant transmissivity; and enhanced connectivity of the fracture network due to the occurrence of fractures belonging to different sets.

Although the correlation between high flow evidence and high dQ cannot be demonstrated, the analysis of all flow evidence classes, with respect to all dQ classes (Tab. 4), suggests the existence of a correlation between high flow evidence and significant dQ. It is noteworthy that $77 \%$ of high-FE fractures are in intervals with significant flow rate (dQ), $48 \%$ of them located within high-dQ intervals. On the other hand, 79\% of intermediate-FE, $76 \%$ of low-FE, and $72 \%$ of insignificant-FE classes are located in intervals of insignificant dQ (Tab. 4).

The importance of G1 fractures for the flow in the vertical boreholes is clearly demonstrated, as in 5 of the 13 intervals with significant dQ, G1 is the only present fracture set (Tab.3). From these 13 intervals, the only one in which G1 fractures are not present is in well 256 (208 and 218 m, Fig. 8), with intermediate-dQ of $1.0 \mathrm{~L} / \mathrm{min}$ (Tab. 3). In this interval, G2 and G4 fractures are present in addition to one fracture of G3, which is the only one with high-FE, which suggests that it can be the most transmissive fracture in the interval.

Therefore, the analysis of the logging data indicates that the majority of the transmissive fractures, intercepted by the vertical boreholes, belong to the group of fractures parallel to the foliation (G1). Fernandes et al. (2016), based on fracture surveys conducted in quarries, including observations on flow evidence along fractures, such as weathering and oxidation, also concluded that part of G1 fractures are transmissive. Although vertical borehole data, due to sampling

Table 3. Sixteen segments of boreholes with considerable variation in flow rate (dQ), and fracture sets (G1 to G5) that occur in each of them. $[\mathrm{FEh}]$ and $\{\mathrm{FEi}\}$ number of fractures with high and intermediate flow evidence, respectively.

\begin{tabular}{|c|c|c|c|c|c|c|c|c|c|}
\hline \multirow{2}{*}{$\begin{array}{l}\text { Natural } \\
\text { conditions } \\
\text { dQ }(L / \text { min })\end{array}$} & \multirow{2}{*}{$\begin{array}{c}\text { Pumping } \\
\text { conditions } \\
\text { dQ }(L / m i n)\end{array}$} & \multirow{2}{*}{$\begin{array}{c}\text { Classification } \\
\text { of dQ }\end{array}$} & \multirow{2}{*}{ Depth (m) } & \multirow{2}{*}{$\begin{array}{l}\text { No. of fractures/segment } \\
\text { length }(m)=\text { density }\end{array}$} & \multicolumn{5}{|c|}{$\begin{array}{l}\text { No. of fractures in the interval, } \\
\text { fractures with }[\mathrm{FEh}] \text { and }\{\mathrm{FEi}\}\end{array}$} \\
\hline & & & & & G1 & G2 & G3 & G4 & G5 \\
\hline \multicolumn{10}{|c|}{ WELL 255 - depth ranges with significant dQ } \\
\hline & $>1.2$ & Intermediate & $144-156.5$ & $21 / 12.5=1.7$ & $19[9]$ & 2 & & & \multirow{3}{*}{$2\{2\}$} \\
\hline & 5.1 & High & $156-162$ & $13 / 6 \mathrm{~m}=2.2$ & $11[11]$ & & & & \\
\hline & 0.2 & Low & $173-181$ & $10 / 7 \mathrm{~m}=1.4$ & $4[1]$ & 4 & $2[1]$ & & \\
\hline \multicolumn{10}{|c|}{ WELL 256 - segments with significant dQ } \\
\hline \multirow[t]{2}{*}{-0.3 (input) } & 0.9 & Intermediate & $102-108$ & $14 / 6 \mathrm{~m}=2.3$ & 11 & & 1 & 2 & \\
\hline & 0.7 & Intermediate & $109-115$ & $13 / 6 \mathrm{~m}=2.1$ & $9\{7\}$ & & & & \\
\hline-0.4 & & ${ }^{*}$ Low & $124-132$ & $2 / 8=0.3$ & 2 & & & & \\
\hline-0.6 (output) & 1.0 & Intermediate & $208-218$ & $8 / 10 \mathrm{~m}=0.8$ & & 5 & $1[1]$ & 2 & \\
\hline \multicolumn{10}{|c|}{ WELL 1204 - segments with significant dQ } \\
\hline-1.7 (input) & 2.6 & High & $121-133$ & $27 / 11 \mathrm{~m}=2.5$ & $24[5]\{6\}$ & & 1 & & 1 \\
\hline \multirow[t]{2}{*}{-1.7 (output) } & & Low & $184-186$ & $6 / 2 m=3$ & $6\{2\}$ & & & & \\
\hline & 3.4 & High & $247-255$ & $12 / 8 \mathrm{~m}=1.5$ & 11 & & 2 & 1 & 1 \\
\hline \multicolumn{10}{|c|}{ WELL 1346 - segments with significant dQ } \\
\hline & 1.0 & Intermediate & $81-92$ & $36 / 11 \mathrm{~m}=3.3$ & $36\{2\}$ & & & & \\
\hline & 1.4 & Intermediate & $123-139$ & $13 / 16 \mathrm{~m}=0.8$ & 12 & & & & \\
\hline & 3.5 & High & $163-172$ & $24 / 9 \mathrm{~m}=2.9$ & 24 & & & & \\
\hline
\end{tabular}

dQ: flow rate variation; ${ }^{*} \mathrm{dQ}$ measured under natural conditions. The dQ negative signal means downward flow. 
bias, are not representative with regard to fractures with high dips, high-FE fractures of set G3, at wells 255 (173-181 m) and $256(208-218 \mathrm{~m})$, as well as intermediate-FE fractures of G5 at well 255 (156-162 m), suggest that both G3 and G5 may also play an important role for groundwater flow. Fernandes et al. (2016) suggested that subvertical NE and NW striking fractures, correlated to G3 and G5, respectively, also contain transmissive fractures. Regional lineaments with similar directions (Fig. 4 and Tab. 1) reinforce their importance in the whole region.

These results corroborate those obtained in the literature, which indicates that data collected in boreholes should be integrated with those from geological surveys and hydraulic tests, in order to solve ambiguities (Paillet and Ollila 1994, Paillet and Pedler 1996). Long et al. (1982) concluded that, in order to identify flow patterns in fractured aquifers, connectivity is as important as the aperture (or transmissivity) of individual fractures. This is probably related to the fact that the fractures, locally identified as permeable, are not always connected to the large-scale flow system. The latter can be controlled by connections that cannot be observed in the small exposures provided by the individual borehole loggings (Paillet 1991, Long et al. 1982). Larger-scale flow directions may rather be controlled by fracture zones than by the orientation of specific fractures intercepted by boreholes (Paillet et al. 1987). Shapiro et al. (2007) estimated the hydraulic conductivity of a fractured aquifer over physical dimensions ranging from meters to kilometers. Single-hole hydraulic tests, at few meter scale, showed a range of hydraulic conductivity from 10-10 to 10-4 m/s. Cross-borehole hydraulic tests, at distances ranging from 10 to $100 \mathrm{~m}$, showed the presence of highly transmissive fractures, with a hydraulic conductivity of approximately $10-4 \mathrm{~m} / \mathrm{s}$. However, over dimensions of $100 \mathrm{~m}$ the bulk hydraulic conductivity of the fractured rock was controlled by the less conductive fractures, with a hydraulic conductivity of approximately $10-7 \mathrm{~m} / \mathrm{s}$. Over dimensions of kilometers, the background network of less transmissive fractures appears to control the bulk hydraulic conductivity of the rock. The authors concluded that the integration of information from the geologic and fracture mapping, in boreholes and exposures of rocks, was needed to both formulate hypotheses and interpret hydraulic properties of the fractured rock over increasingly large physical dimensions.
Unlike the region studied by Shapiro et al. (2007), where the fractures mapped on road cuts show poor connectivity and trace lengths that rarely exceed $10 \mathrm{~m}$, in the region of the present study, the individual subhorizontal and subvertical fractures can reach more than a hundred meters, and are at least partially connected, as observed in the quarries (Fernandes et al. 2016). In situations in which the transmissive fractures are connected, contaminants may migrate, either sideways or vertically, probably more than a few hundred meters. The collection of hydraulic, hydrochemical and isotope data should be conducted in order to confirm the existence of this transmissive and connected large-scale flow system. Additionally, in order to characterize the subvertical fractures in Jurubatuba site, inclined boreholes should be drilled, and fracture surveys along them, through OPTV and/or ATV loggings, should be conducted.

\section{CONCLUSION}

The analyzed boreholes crosscut gneisses, with bands of pegmatites and schists, and, secondarily, migmatites. The foliation, N40-50E predominantly striking, is affected by asymmetric cylindrical folds with NE striking axis. The comparison of the local and regional lineaments with fractures, measured in outcrops and boreholes, showed that most trends are common to all, with some divergences, such as trend NE, which stands out for the regional lineaments, but is almost non-existent in outcrops. This occurs because the fractures of this direction resulted, in great extent, from the reactivation of the foliation and lithological contacts, present in the metamorphic rocks, but absent in most of the surveyed outcrops, which are constituted of massive granites. The NS direction stands out in the lineament rose diagrams, but is absent in the outcrops and is secondary in the boreholes. N20-50W is a major trend in outcrops and regional lineaments, but is subordinate in the local lineaments and absent in boreholes, suggesting to be less important in the study area.

The fractures of G1, by far the predominant set intercepted by the wells, are generally parallel to the foliation, and dip from 10 to $40^{\circ}$ towards NW or SE, following the great circles drawn by the foliation poles. Its average spacing remains practically constant in the four wells, around $0.7 \mathrm{~m}$. Although the vertical boreholes do not allow the estimation of representative spacings of the high dip fractures (G2, G3, and G5), it was

Table 4. Relationships between flow evidence (FE) and variation in flow rate (dQ) of fractures. Fractures that occur at depth intervals wit loss of efficiency, for the flowmeter readings, were excluded from this analysis.

\begin{tabular}{lccccc}
\hline \multirow{2}{*}{ Flow Evidence (FE) of fractures } & \multicolumn{4}{c}{ Variation in flow rate (dQ) in segments } & \multirow{2}{*}{ Total } \\
\cline { 2 - 5 } & High-dQ & Intermediate-dQ & Low-dQ & Insignificant-dQ & \\
\hline Number of fractures high-FE & $17(48 \%)$ & $9(24 \%)$ & $2(5 \%)$ & $10(26 \%)$ & $38(5 \%)$ \\
Number of fractures intermediate-FE & $10(14 \%)$ & $2(3 \%)$ & $3(4 \%)$ & $57(79 \%)$ & $72(8 \%)$ \\
Number of fractures low-FE & $22(6 \%)$ & $62(16 \%)$ & $10(2,6 \%)$ & $289(75 \%)$ & $383(45 \%)$ \\
Number of fractures insignificant-FE & $30(18 \%)$ & $67(19 \%)$ & $3(1 \%)$ & $258(72 \%)$ & $358(42 \%)$ \\
TOTAL & $79(9 \%)$ & $140(17 \%)$ & $18(2 \%)$ & $614(72 \%)$ & 851 \\
\hline
\end{tabular}


shown that it is possible to identify those fracture sets in the wells, allowing not only the comparison with the ones characterized in outcrops but also the correlation with the lineament trends (Fig. 4). G2 appears in the four wells, which reinforces the importance of the EW direction, which is the second most important trend of the local lineaments. Due to its intermediate dip, spacing of G4 (EW striking) was considered to be representative and is bimodal, ranging from 9 to 14 $\mathrm{m}$ and from 95 to $160 \mathrm{~m}$.

Based on visual characteristics observed in optical and acoustic images, fractures were classified with regard to the $\mathrm{FE}$ as insignificant-FE, low-FE, intermediate-FE and high-FE. The flowmeter logging allowed the identification of 13 intervals, responsible for a certain amount of flow (dQ), which was classified as low-dQ $(0.2$ to $0.6 \mathrm{~L} / \mathrm{min})$, intermediate-dQ $(0.6$ to $2.0 \mathrm{~L} / \mathrm{min})$ and high-dQ $(>2.0 \mathrm{~L} / \mathrm{min})$; in the remaining portions of the boreholes $d Q$ is insignificant $(<0.2 \mathrm{~L} / \mathrm{min})$. Seventy-four percent of fractures with high-FE occur in intervals with significant flow rate (dQ), indicating a positive correlation between those factors. More than $70 \%$ of fractures with insignificant, low and intermediate-FE are located in segments with insignificant dQ $(<0.2 \mathrm{~L} / \mathrm{min})$. However, five intervals with significant flow rate (low, intermediate and high-dQ) contain only fractures with low and insignificant-FE, implying that these could also be transmissive. It implies that the visual classification of flow evidence alone is not appropriate to identify transmissive fractures.

The importance of G1 fractures for the flow in the vertical boreholes is clearly demonstrated, as in 5 of the 13 intervals with significant $d Q, G 1$ is the only present fracture set. The data are inconclusive with respect to flow evidence in high dip fractures, as few were traversed by the boreholes. However, data from boreholes provide some evidence that G3 and G5 are also transmissive, which corroborates the results achieved from the fracture survey data conducted in outcrops. Furthermore, the presence of major NE and NW regional lineament trends reinforces the importance of such groups in the region as a whole.

It is important to emphasize that fractured aquifer investigations will probably undergo the following methodological limitations:

- outcrops may be rare, mainly in urban areas, being necessary to seek them in more distant locations, despite increasing uncertainties regarding fracture characterization;

- pre-existing production boreholes, in which the geophysical surveys may be conducted, are vertical and, therefore, spacings with respect to highly $\left(>60^{\circ}\right)$ dipping fractures will not be representative;

- in flowmeter loggings, the flow rates are measured for depth intervals in which several fractures (often belonging to different sets) are present, making it difficult to assign higher transmissivities to specific fractures;

- variations of borehole diameter (common in production wells) cause distortions on the flowmeter measurements, as the diverter does not work properly;

- and the boreholes do not allow to characterize fracture length and connectivity.

In order to reduce the uncertainties that will arise due to the methodological limitations mentioned above, lineament analysis at a detailed scale (e.g., DTM based on 1:10,000 topographic maps) is recommended, as they indicate the trends of subvertical structures and, thus, complement the data from boreholes, where the visualization of low to intermediate dip fractures is privileged. The lineaments can also be used as a means of making correlations between fracture sets identified in wells, on one hand, and the ones characterized at rock exposures, on the other. The results achieved in this study demonstrate that the joint analysis of borehole, lineaments, at local and regional scales, and data obtained by detailed survey of fracture attributes on rock exposures can be used to minimize the uncertainties inherent to the exclusive analysis of fractures along boreholes profilings. Therefore, surveys on large outcrops are strongly recommended, as they provide data on spacing, length, indication of flow along specific fractures, as well as of physical connectivity between the fracture sets, a factor considered in the literature as important as the aperture.

\section{ACKNOWLEDGEMENTS}

The authors are grateful to the Institute for Technological Research (IPT) for the availability of the OPTV probe used in the geophysical loggings and for the involvement of their researcher, Carlos A. Birelli. They are also thankful to: Lucas A. Ribeiro for his participation in field activities; the G360 Institute for Groundwater Research of the University of Guelph (Canada), in the person of Dr. Beth Parker, for collaborating and training the staff to use the equipment and software; the ALT company for granting WELLCAD licenses. The authors are especially thankful to Financiadora de Estudos e Projetos (FINEP) (1824/10), Fundação de Amparo à Pesquisa do Estado de São Paulo (FAPESP) (10311-3) and the Prosecuting Council of the State of São Paulo (TAC 25/09) for funding the Jurubatuba Project; and finally to CAPES and FAPESP (2011/04169-4) for granting the master's scholarship to Bruna Fiume. Finally, the authors are thankful to two of the BJG reviewers for their important contributions that improved the quality of this paper.

\section{ARTICLE INFORMATION}

Manuscript ID: 20190034. Received on: 05/20/2019. Approved on: 03/23/2020.

B.F. wrote the first draft of the manuscript and prepared Figures 1 to 6; A.J.F. provided advisorship regarding borehole geophysics and structural geology and improved the manuscript through corrections and suggestions. M.B.B. was responsible for the geophysical loggings and prepared Figures 7 to 10. R.H. was responsible for the project and revised and improved the manuscript. R.B. coordinated the project, provided advisorship regarding borehole geophysics and fractured rock hydrogeology and improved the manuscript through suggestions.

Competing interests: The authors declare no competing interests. 


\section{REFERENCES}

Alves F.M. 2008. Tectônica rúptil aplicada ao estudo de aquífero em rochas cristalinas fraturadas na região de Cotia. Dissertation, Instituto de Geociências, Universidade de São Paulo, São Paulo, 116 p.

Companhia de Saneamento Básico do Estado de São Paulo (SABESP)/ Centro de Pesquisas de Águas Subterrâneas (CEPAS-IGc-USP). 1994. Diagnóstico hidrogeológico da Região Metropolitana de São Paulo - Diagnóstico Final. Relatório final. São Paulo: Convênio SABESP/CEPAS-IGc-USP, 115 p.

Fernandes A.J. 2008. Aquíferos fraturados: uma revisão dos condicionantes geológicos e dos métodos de investigação. Revista do Instituto Geológico, 29(1-2):49-72. http://dx.doi.org/10.5935/0100-929X.20080005

Fernandes A.J., Fiume B., Bertolo R., Hirata R.C.A. 2016. Modelo geométrico de fraturas e análise da tectônica rúptil aplicados ao estudo do fluxo do aquífero cristalino, São Paulo (SP). Geologia USP, Série Científica, 16(3):71-88. http://dx.doi.org/10.11606/issn.2316-9095.v16i3p71-88

Fernandes A.J., Maldaner C.H., Rouleau A. 2011. Análise das fraturas nos basaltos de Ribeirão Preto, SP: aplicação à elaboração de modelo hidrogeológico conceitual. Geologia USP, Série Científica, 11(3):43-64. http://dx.doi.org/10.5327/Z1519-874X2011000300003

Fernandes A.J., Perrota M.M., Salvador E.D., Azevedo S.G., Gimenez Filho A., Stefani F.L., Paulon N. 2005. Aquíferos fraturados. In: Governo do Estado de São Paulo (ed.), Mapa de águas subterrâneas do Estado de São Paulo (escala 1:1.000.000). Brasil, DAEE/IG/IPT/CPRM, p. 66-84.

Fiume B. 2013. Geologia estrutural de detalhe para elaboração de modelo conceitual de circulação de água subterrânea: estudo de caso em Jurubatuba, SP. Dissertation, Instituto de Geociências, Universidade de São Paulo, São Paulo, 165 p.

Hart S.T., Sciulli B.E., Cho J., Alves F.M. 2007. Conceptual Model of Tropically Weathered and Fractured Crystalline Bedrock and its Implications for In Situ Chemical Oxidation. In: NGWA Fractured Rock Conference. Proceedings ... p. 357-369.

Hess A.E. 1986. Identifying hydraulically conductive fractures with a slowvelocity borehole flowmeter. Canadian Geotechnical Journal, 23(1):69-78.

Johnson C.D., Haeni F.P., Lane Jr. J.W., White E.A. 2002. Borehole-geophysical investigation of the University of Connecticut landfill, Storrs, Connecticut. Georgia: US Geological Survey, Water-Resources Investigations Report 01-4033, 50 p.

Johnson C.D., Williams J.H. 2003. Hydraulic logging methods - A summary and field demonstration in Conyers, Rockdale County, Georgia. In: Williams L.J. (Ed.). Methods used to assess the occurrence and availability of ground water in fractured-crystalline bedrock: An excursion into areas of Lithonia Gneiss in eastern metropolitan Atlanta, Georgia. Georgia: Geologic Survey. p. 40-47. Guidebook 23.

Keys W.S. 1979. Borehole geophysics in igneous and metamorphic rocks. In: Annual Logging Symposium, 20, Transactions... Society of Professional Well Log Analysts, p. 1-26.

L'apiccirella E.S.P. 2009. Contaminação e áreas de restrição de uso de água subterrânea no entorno do canal Jurubatuba em São Paulo - SP. MS Dissertation, Instituto de Geociências, Universidade de São Paulo, São Paulo, 125 p.

Long J.C.S., Remer J.S., Wilson C.R., Witherspoon P.A. 1982. Porous media equivalents for networks of discontinuous fractures. Water Resources Research, 18(3):645-658. https://doi.org/10.1029/WR018i003p00645

Morin R.H., Carleton G.B., Poirier S. 1997. Fractured-aquifer hydrogeology from geophysical logs; The Passaic Formation, New Jersey. Ground Water, 35(2):328-338. https://doi.org/10.1111/j.1745-6584.1997.tb00090.x

Morin R.H., Senior L.A., Decker E.R. 2000. Fractured-aquifer hydrogeology from geophysical logs: Brunswick Group and Lockatong Formation, Pennsylvania. Ground Water, 38(2):182-192. https://doi. org/10.1111/j.1745-6584.2000.tb00329.x
Oliveira D.G.G., Monteiro M.D., Massoni F., Rocha H.C. 2012. Televisionamento de Furos de Sondagens nos Estudos do Metrô de São Paulo - Proposta Metodológica para Execução e Análise. Revista Brasileira de Geologia de Engenharia e Ambiental, 2(1):95-114.

Paillet F.L. 1991. Use of geophysical well logs in evaluating crystalline rocks for siting of radioactive waste repositories. The Log Analyst, 32(2):85-107.

Paillet F.L. 1994. Application of borehole geophysics in the characterization of flow in fractured rocks. Denver: U.S. Geological Survey, 39 p. https://doi. org/10.3133/wri934214

Paillet F.L. 1995. Using borehole flow logging to optimize hydraulic-test procedures in heterogeneous fractured aquifers. Hydrogeology Journal, 3(3):4-20. https://doi.org/10.1007/s100400050249

Paillet F.L. 2004. Borehole flowmeter applications in irregular and largediameter boreholes. Journal of Applied Geophysics, 55(1):39-59. https:// dx.doi.org/10.1016/j.jappgeo.2003.06.004

Paillet F.L., Barton C., Luthi S., Rambow F., Zemanek J. 1990. Borehole Imaging. Houston: Society of Professional Well Log Analysts, 472 p. SPWLA Reprint Series.

Paillet F.L., Hess A.E., Cheng C.H., Hardin E.L. 1987. Characterization of fracture permeability with high-resolution vertical flow measurements during borehole pumping. Ground Water, 25(1):28-40. https://doi. org/10.1111/j.1745-6584.1987.tb02113.x

Paillet F.L., Ollila P. 1994. Identification, characterization and analysis of hydraulic conductive fractures of granitic basement rocks, Massachusetts. Denver: U.S. Geological Survey, 38 p.

Paillet F.L., Pedler H.W. 1996. Integrated borehole logging methods for wellhead protection applications. Engineering Geology, 42(2-3):155-165. https://doi.org/10.1016/0013-7952(95)00077-1

Perrotta M.M., Salvador E.D., Lopes R.C., D’agostinho L.Z., Peruffo N., Gomes S.D., Sachs L.L., Meira V.T., Garcia M.G.M., Lacerda Filho J.V. 2005. Mapa Geológico do Estado de São Paulo, escala 1:750.000. São Paulo: Programa Geologia do Brasil-PGB, CPRM.

Pino D.S. 2012. Structural Hydrogeology in the Kenogamy Uplands, Quebec, Canada. MS Dissertation, L'Université du Québec à Chicoutimi, Quebec, 184 p.

Shapiro A.M., Hsieh P.A., Burton W.C., Walsh G.J. 2007. Integrated multiscale characterization of ground-water flow and chemical transport in fractured crystalline rock at the Mirror Lake Site, New Hampshire. In: Hyndman D.W., Day-Lewis F.D., Singha K. (eds.), Geophysical Monograph. New Hampshire, v.171, p.201-225. https://doi.org/10.1029/171GM15

Stumm F., Chu A., Lange A.D., Paillet F.L., Williams J.H., Lane Jr. J.W. 2001. Use of advanced borehole geophysical techniques to delineate fracturedrock ground-water flow and fractures along water-tunnel facilities in northern Queens County, New York. Denver: U.S. Geological Survey, Water-Resources Investigations Report 00-4276, $12 \mathrm{p}$.

Terzaghi R.D. 1965. Sources of error in joint surveys. Geotechnique, 15(3):287-304. https://doi.org/10.1680/geot.1965.15.3.287

Wahnfried I. 2010. Modelo conceitual de fluxo do aquitarde Serra Geral e do Sistema AquÍfero Guarani na Região de Ribeirão Preto, SP. PhD Thesis, Instituto de Geociências, Universidade de São Paulo, São Paulo, 124 p.

Williams J.H., Johnson C.D. 2004. Acoustic and optical borehole-wall imaging for fractured-rock aquifer studies. Journal of Applied Geophysics, 55(1-2):151-159. https://doi.org/10.1016/j.jappgeo.2003.06.009

Williams J.H., Paillet F.L. 2002. Characterization of fractures and flow zones in a contaminated shale at the Watervliet Arsenal, Albany County, New York. Denver: U.S. Geological Survey, Open-File Report 01-385, 25 p. 